\title{
Research on the Current Situation of College Students' Physical Health in Different Majors at Shanghai Maritime University
}

\author{
Huan-Qi CHI \\ (Department of Sport, Shanghai Ocean University, Shanghai 201306, China)
}

Keywords: different majors; fitness test; physical improvement

\begin{abstract}
This study took the students' physical health status as the research object, combined with the physical measurement data over the years, and conducted data analysis on the students' physique status of Shanghai Maritime University from two angles. They studied the students' height, weight, physical function and physical quality. Numerical value. Aim to explore the status of college students physical health. The study found that the physical fitness of Shanghai Maritime University students is not very good, except for the flexibility to achieve better than the other test results are just passed the project. The decline in endurance and upper arm muscle strength was the most obvious, and the speed dexterity and explosiveness of lower extremity muscles also decreased. The decline in physical fitness of girls was more pronounced than that of boys .We studied the students in the physical quality of the specific values. The purpose is to explore the status of college students' physical health in different specialties. The study found that the physical fitness of Shanghai Maritime University students is not very good, except for the flexibility to achieve better than the other test results are just passed the project. The decline in endurance and upper arm muscle strength was the most obvious, and the speed dexterity and explosiveness of lower extremity muscles also decreased. The decline in physical fitness of girls was more pronounced than that of boys. The study found that the physical fitness of Shanghai Maritime University students is not very good, except for the flexibility to achieve better than the other test results are just passed the project.
\end{abstract}

\section{Research Purposes}

Recent research data show that the physical health of students has dropped significantly and cause widespread concern in society. The report on the physical status of students has directly influenced the formulation of international policies, and the decline in constitutional quality is also a major problem in recent years. All countries are also actively adopting various measures to cope with changes under such new circumstances, and strive to get out of this vicious circle as soon as possible to gain a dominant position in the competition for human resources. This article studies the current status of college students' physical fitness tests in different majors, and strives to provide a theoretical basis for improving college students' physical fitness.

\section{Research Methods}

\section{Method of Test}

Through on-site tests, the students of five professional classes in 2016 were assessed for height, weight, vital capacity, 1,000-meter run / 800-meter run for women, Sitting body flexion test.

\section{Mathematical Statistics}

The mean \pm standard deviation (SSA) and the heteroscedasticity test (T-test) were used to test the performance of different subjects in five major professional subjects of 2015 grade by Excel. In addition, GraphPad Prism 5 software was used to analyze the physical test scores The mean \pm standard deviation was analyzed. 


\section{Results and Analysis of Research}

\section{Analysis of Students' Vital Capacity Test Results}

Table 1 Student's Vital Capacity Test Results (mL)

\begin{tabular}{|c|c|c|}
\hline Major & Male & Female \\
\hline $\begin{array}{c}\text { International } \\
\text { shipping }\end{array}$ & $3531.18 \pm 758.20$ & $2617.29 \pm 946.73$ \\
\hline $\begin{array}{c}\text { Economic } \\
\text { management }\end{array}$ & $4770.27 \pm 729.07$ & $2833.47 \pm 735.45$ \\
\hline Navigation & $3368.74 \pm 788.17$ & $2466.14 \pm 608.08$ \\
\hline Mechanical & $3807.44 \pm 1373.57$ & $2762.65 \pm 412.31$ \\
\hline Computer & $3233.1 \pm 821.43$ & $2177.09 \pm 390.15$ \\
\hline
\end{tabular}

The result of Table 1 shows that the male students of different majors have significantly higher degrees of economic management than those of International shipping $(p<0.05)$. The marital abilities of boys in sailing, mechanics and computer science were significantly lower than that in economics and management $(\mathrm{p}<0.05)$. Computer major was significantly lower than that of maritime specialty ( $<<0.05$ ), while there was no significant difference between the four majors of Maritime specialty, mechanical, Computer and International shipping. In addition, there was no significant difference in lung capacity between girls of International shipping' s professional and economic management majors. On the contrary, the girls' vital capacity was significantly lower than that of economics and management $(p<0.05)$. There was no significant difference in the girl's vital capacity between the three majors of International shipping, Navigation and Computer.

\section{Analysis of Sit and Body Flexion Test Results}

Table 2 Result of seat body flexion test(cm)

\begin{tabular}{|c|c|c|}
\hline Major & Male & Female \\
\hline $\begin{array}{c}\text { International } \\
\text { shipping }\end{array}$ & $14.67 \pm 5.70$ & $14.09 \pm 4.68$ \\
\hline $\begin{array}{c}\text { Economic } \\
\text { management }\end{array}$ & $19.78 \pm 3.27$ & $16.03 \pm 5.33$ \\
\hline Navigation & $9.57 \pm 4.91$ & $13.08 \pm 5.39$ \\
\hline Mechanical & $13.32 \pm 6.08$ & $15.87 \pm 5.13$ \\
\hline Computer & $9 \pm 7.02$ & $12.27 \pm 4.78$ \\
\hline
\end{tabular}

The result of Table 2 shows that compared with seated individuals in different professions, the female students of Economic management were significantly higher than that of International shipping $(\mathrm{p}<0.05)$. Boys of Navigation and Computer majors were significantly lower than those of International shipping $(\mathrm{p}<0.05)$. Boys in Navigation, Mechanical and Computer majors were significantly lower than those in Economic management $(\mathrm{p}<0.05)$.In the comparison of seated body flexion among female students of different specialties in this year, the forward flexion of the International shipping and Computer professional seats was significantly lower than that of the Economic management profession $(\mathrm{p}<0.05)$. 


\section{Analysis of 50-Meter Run Test Results}

Table 3 Results of the Student's 50-Meter Run Test (s)

\begin{tabular}{|c|c|c|}
\hline Major & Male & Female \\
\hline $\begin{array}{c}\text { International } \\
\text { shipping }\end{array}$ & $8.07 \pm 1.21$ & $8.79 \pm 1.49$ \\
\hline $\begin{array}{c}\text { Economic } \\
\text { management }\end{array}$ & $7.33 \pm 0.41$ & $9.33 \pm 0.74$ \\
\hline Navigation & $7.71 \pm 0.52$ & $10.27 \pm 0.67$ \\
\hline Mechanical & $6.12 \pm 0.50$ & $9.35 \pm 1.09$ \\
\hline Computer & $8.05 \pm 0.74$ & $10.59 \pm 1.33$ \\
\hline
\end{tabular}

In the 50-meter test data of 2016, compared with 50 meters of different professional boys, International shipping majors were significantly lower than those of economic management and mechanical majors $(\mathrm{p}<0.05)$, and economic management majors were significantly lower than mechanical majors $(\mathrm{p}<0.05)$. Navigational and computer majors were significantly lower than those of economic management $(\mathrm{p}<0.05)$, mechanical specialties were significantly higher than navigational specialties $(\mathrm{p}<0.05)$, and computer specialties were significantly lower than mechanical specialties ( $<<0.05$ ); In addition, during the comparison of the 50 -meter female students of different specialties in this year, navigation and computer majors were significantly lower than those of International shipping $(\mathrm{p}<0.05)$, and navigation and computer majors were also significantly lower than those of economic management $(\mathrm{p}<0.05)$.

\section{Analysis of Student Long Jump Test Results}

Table 4 Analysis of student long jump test results(m)

\begin{tabular}{|l|c|c|}
\hline Major & Male & Female \\
\hline $\begin{array}{l}\text { International } \\
\text { shipping }\end{array}$ & $219.08 \pm 24.06$ & $187.29 \pm 18.10$ \\
\hline $\begin{array}{l}\text { Economic } \\
\text { management }\end{array}$ & $227.82 \pm 14.89$ & $167.91 \pm 13.14$ \\
\hline Navigation & $222.04 \pm 16.94$ & $163.11 \pm 13.11$ \\
\hline Mechanical & $210.83 \pm 20.30$ & $171.03 \pm 14.87$ \\
\hline Computer & $209.07 \pm 27.58$ & $150 \pm 23.13$ \\
\hline
\end{tabular}

Compared with boys' long jump performances in different disciplines, the mechanical and computer majors were significantly lower than the navigation majors $(p<0.05)$. While there were no significant differences between the International shipping, economic management, mechanical and computer majors; Comparing the girls' long-term results of different professional, the result of International shipping were significantly higher than those of navigational and computer majors $(\mathrm{p}<0.05)$.And economic management majors were significantly higher than those of computer majors $(\mathrm{p}<0.05)$. There were no significant differences between the maritime and computer majors. 


\section{Analysis of Pull-Up (Male)/Sit-Up (Female) Test Results}

Table 5 Analysis of pull-up (male)/sit-up (female) test results(number)

\begin{tabular}{|c|c|c|}
\hline Major & Male & Female \\
\hline $\begin{array}{c}\text { International } \\
\text { shipping }\end{array}$ & $6.32 \pm 4.31$ & $32.85 \pm 6.44$ \\
\hline $\begin{array}{c}\text { Economic } \\
\text { management }\end{array}$ & $8.73 \pm 4.50$ & $38.24 \pm 4.61$ \\
\hline Navigation & $7.39 \pm 3.26$ & $31.66 \pm 5.70$ \\
\hline Mechanical & $4.54 \pm 3.90$ & $26.74 \pm 8.29$ \\
\hline Computer & $3.97 \pm 3.92$ & $22.45 \pm 5.41$ \\
\hline
\end{tabular}

Compared with boys' pull-ups in different disciplines, International shipping, economic management majors and navigation majors were significantly higher than those of mechanical majors $(\mathrm{p}<0.05)$. Results of International shipping, economic management and navigation were also significantly higher than those of computer majors $(\mathrm{p}<0.05)$. There were no significant differences between International shipping, economic management and navigation majors. There was no significant difference between the mechanical and computer majors. In addition, during the comparison of the sit-ups between different professional girls in the same year, Results of International shipping significantly lower than the Economic management professional $(\mathrm{p}<0.05)$, the Economic management profession is significantly higher than the Navigation profession $(\mathrm{p}<0.05)$, the Computer profession is significantly lower than the national aviation professional, economic management professional and navigation professional $(\mathrm{p}<0.05)$.

\section{Analysis of Test Results for 1000 Meters (Male)/800 Meters (Female)}

Table 6 Analysis of test results for 1000 meters (male)/800 meters (female)

\begin{tabular}{|l|c|c|}
\hline Major & Male & Female \\
\hline $\begin{array}{l}\text { International } \\
\text { shipping }\end{array}$ & $4.49 \pm 0.83$ & $4.05 \pm 0.61$ \\
\hline $\begin{array}{l}\text { Economic } \\
\text { management }\end{array}$ & $4.13 \pm 0.13$ & $4.1 \pm 0.28$ \\
\hline Navigation & $4.14 \pm 0.13$ & $4.06 \pm 0.24$ \\
\hline Mechanical & $4.11 \pm 0.56$ & $3.89 \pm 0.41$ \\
\hline Computer & $4.9 \pm 0.71$ & $4.38 \pm 0.13$ \\
\hline
\end{tabular}

Comparing the results of $1000 \mathrm{~m}$ running in boys of different specialties, the three specialties of economics management, navigation and mechanical majors are significantly higher than those of International shipping $(\mathrm{p}<0.05)$. While the computer majors are significantly lower than those of International shipping, economic management and navigation majors $(\mathrm{p}<0.05)$. There were no significant differences among the three professional departments of economic management, navigation and mechanics; In the comparison of 800 meters of girls of different specialties, economic management and mechanical majors were significantly higher than those of computer science $(\mathrm{p}<0.05)$. There are no significant differences between International shipping economic management and navigation majors. 


\section{Conclusions and Recommendations}

\section{Conclusion}

The comparative analysis of the test results of seat-body forward flexion among students of different specialties shows that male and female students in economic management are significantly higher than those in other professional departments. And male students in mechanical majors are significantly higher than those in navigation and computer majors. The results of the 50 -meter test showed that mechanical professional performance was significantly higher than that of the other four professional students. The comparative analysis of the long jump test results shows that the navigation profession is significantly higher than the mechanical and computer majors, and the female International shipping profession is significantly higher than other professional departments. The scores of male students in International shipping majors, economic management majors and navigation majors are significantly higher than those of mechanical majors and computer majors. The results of female students in economic management majors in sit-ups are significantly higher than those of other professional departments. Boys with a computer major have a test score of 1,000 meters significantly lower than the other four professional departments; the 800-meter test for girls is also significantly lower than other professional departments.

\section{Suggestions}

Leaders of school should strengthen the correct guidance for students' physical fitness training, ensure the implementation of national policies and improve physical training facilities. As far as possible to meet the needs of students. And ensure adequate facilities and equipment for physical training. At the same time, students' test scores and exercise behaviors should be appropriately divided according to the professional and reasonable methods, with targeted organization, guidance, supervision and management of students' physical exercise behaviors and training habits.

Schools should continue to vigorously develop the activities of sports-related associations and groups. Correctly guide students to choose the form of collective sports, mobilize students' motivation for sports and increase the atmosphere of sports. At the same time, we will focus on strengthening students' communicative competence and improving students' scientific exercise behavior and persistence.

\section{References}

[1] Wang Cheng, Sun Wei, Chen Shanping. Research on the development trend of students' physical fitness.[J]. Journal of Beijing Sport University, 2005,28(10):1378-1389.

[2] Bao Xueming, Zhu Liansheng. Analysis of Physical Fitness Test Indexes of China, Japan and Singapore.[J].Sport Science and Technology,2002,23(2):55-56.

[3] Liu Guoli. Research on the differences of physical fitness between China and Japan. [J]. Science and Technology Information, 2014, 12(5): 125-127.

[4] Shen Xunzhang. Past, present and future of national constitution research.[J]. Shanghai Sports Research, 2003, 24(2):51-54.

[5] Fan Yi. Investigation and research on the status quo of implementation of "National Student Physical Health Standards" in Hunan universities [D]. Changsha: Hunan University of Science and Technology, 2010.

[6] Fu Jiliang. Experimental Study on the Index System of "Students' Physical Health Standard" [D]: Hangzhou: Zhejiang University, 2002.

[7] Guo H L. Research on the construction of an evaluation index system for the monitoring of students' physical health in Shanghai [D]: Shanghai: Shanghai Jiao Tong University, 2013.

[8] Zhang Fusheng. Analysis and research on the constitution and health status of students in some 
colleges and universities in Changchun City [D]: Beijing: Beijing Sport University, 2005.

[9] Xie Yubao. Research on the physical health of female students in Zhangzhou University [D]: Beijing: Beijing Sport University, 2008. 